\title{
Expanding implementation of an on-line measurement system of topsoil compaction in loamy sand, loam, silt loam and silt soils
}

\author{
Abdul Mounem Mouazen ${ }^{\mathrm{a} *}$, Herman Ramon $^{\mathrm{b}}$ \\ ${ }^{a}$ Natural Resources Department, Cranfield University, MK43 OAL, United Kingdom, Tel.: \\ +44 1234750111 , Fax: +441234752971 \\ ${ }^{\mathrm{b}}$ Department of Biosystems, Division of Mechatronics, Biostatistics and Sensors (MeBios), \\ Faculty of Bioscience Engineering, Catholic University of Leuven, Kasteelpark Arenberg \\ 30, B-3001, Belgium, e-mail of corresponding author: a.mouazen@ cranfield.ac.uk
}

\section{Abstract}

A previously developed model for on-line prediction of soil compaction indicated as bulk density (BD), was limited in use for a sandy loam field. This study was undertaken to investigate the possibility of modifying this model for new soil textures, namely loamy sand, loam, silt loam and silt loam/silt soils. Using the on-line measurement system of BD, measurements were carried out in 4 fields with different average textures of loam, sandy loam and silt loam and silt loam/silt fields. The on-line measurement system used consisted of a subsoiler, whom draught (D) was measured with a single shear beam load cell and depth (d) was measured with a wheel gauge consisted of a swinging arm metal wheel equipped with a linear variable differential transducer (LVDT). The soil gravimetric moisture content (MC) was measured with the oven drying method. The on-line measured BD was compared with measured BD with Kopecki rings (core sampling method) (736 samples), to validate the potential use of this sensor in the new studied soil textures.

Results showed that the BD model can be used for on-line measurement of soil compaction for the selected textures. It was found that the correction factor (M) of this model was mainly sensitive to variable $\mathrm{MC}$, and slightly sensitive to clay content. The $\mathrm{M}$ at field scale varied between 0.994 (silt loam/silt soil with an average MC of $0.279 \mathrm{~kg} \mathrm{~kg}^{-1}$ ) and 1.171 
1 (loam soil with an average MC of $0.105 \mathrm{~kg} \mathrm{~kg}^{-1}$ ). At almost the same texture, $\mathrm{M}$ varied

2 between 1.171 for an average MC of $0.105 \mathrm{~kg} \mathrm{~kg}^{-1}$ and 1.122 for an average MC of 0.186

$3 \mathrm{~kg} \mathrm{~kg}^{-1}$, which proves the domination of MC effect on $\mathrm{M}$. The multiple linear regression

4 (MLR) analysis (ANNOVA) performed between MC and clay and M retained MC as M

5 predictor $\left(P<0.001, R^{2}=0.86\right)$. This MLR resulted in similar prediction accuracy of

6 compacted zones as compared to the linear regression model between MC and M. In a

7 variable texture field, the corrected BD model resulted in remarkable spatial similarity of

8 BD between the corrected on-line and core sampling method. Therefore, it can be

9 concluded that the BD model with the new M can be used for on-line measurement of soil

10 compaction in loamy sand, sandy loam, loam, silt loam, and silt soils at different MC,

11 bearing in mind that the difference in clay content is minimal (83 to $\left.175 \mathrm{~g} \mathrm{~kg}^{-1}\right)$.

Keywords: bulk density; on-line measurement; sensor; texture; mapping.

*Corresponding Author. Tel.: + 441234 750111; Fax: +44 1234752971

e-mail: a.mouazen@cranfield.ac.uk

\section{Introduction}

Soil compaction owing to the impact of the natural factors, heavy agricultural machinery and improper tillage system limits plant growth and crop yield (Vrindts et al., 2005). This phenomenon can cause increase in the bulk density (BD) and penetration resistance, while decrease in porosity and void ratio takes place. This leads to changes in the hydraulic properties of soil, especially the decrease of the saturated conductivity and the air filled 


\section{Soil and Tillage Research, Volume 103, Issue 1, April 2009, Pages 98-104}

1 porosity at a suction of -50 or $-100 \mathrm{~cm} \mathrm{H}_{2} \mathrm{O}$, which is much more important than the

2

7 high as $1.6 \mathrm{Mg} \mathrm{m}^{-3}$, depending on their conditions. A variation from 1.2 to $1.8 \mathrm{Mg} \mathrm{m}^{-3}$ may

8 be found in sands and sandy loams. Very compacted subsoils may have BD values of 2.0 $9 \mathrm{Mg} \mathrm{m}^{-3}$ or even greater. Grossman (1981) proposed non-limiting BD values for plant 10 growth of $1.3 \mathrm{Mg} \mathrm{m}^{-3}$ and $1.6 \mathrm{Mg} \mathrm{m}^{-3}$ for clayey and sandy soils, respectively. Root limiting increase in BD. However, the on-line measurement of soil compaction can only be realistically done by indirect measurement of $\mathrm{BD}$ or penetration resistance. Unlike the penetration resistance, $\mathrm{BD}$ seems more likely to represent soil compaction, since it is not affected by moisture content (MC) during measurement. Bardy (1984) reported that the BD values of clay, clay loam, and silt loam surface soils normally may range from 1.0 to as high as $1.6 \mathrm{Mg} \mathrm{m}^{-3}$, depending on their conditions. A variation from $1.2 \mathrm{to} 1.8 \mathrm{Mg} \mathrm{m}^{-3}$ may BD values of $1.47 \mathrm{Mg} \mathrm{m}^{-3}$ and $1.85 \mathrm{Mg} \mathrm{m}^{-3}$ were proposed by Grossman and Berdanier (1982) for clayey and sandy soils, respectively. Critical BD values of $1.39 \mathrm{Mg} \mathrm{m}^{-3}$ and 1.69 $\mathrm{Mg} \mathrm{m} \mathrm{m}^{-3}$ were defined for clayey and sandy soil, respectively as the $\mathrm{BD}$ values that correspond to a $20 \%$ increase in total porosity relative to that of the limiting BD. Based on experience, Singh et al. (1992) defined maximum BD value of $2.1 \mathrm{Mg} \mathrm{m}^{-3}$, which may be considered as unrootable by plants.

The measurement of BD by the Kopecki rings (core sampling method) is a labour intensive and time costly procedure; in addition to the discontinuous data output obtained based on fine or coarse measurement grids. Draught and/or penetration resistance were considered to indicate soil compaction (Hemmat and Adamchuk, 2008). They are measured by using different load cells (Sprinkle et al., 1970; Upadhyaya et al., 1984; Hayhoe et al., 2002; Verschoore et al., 2003, Naményi et al., 2006) or strain gauges (Glancey et al., 1989). These mechanical methods provide on-line measurement of soil resistance for a specific 
1 geometry of soil cutting tool, while the most influencing factors affecting the magnitude of

2 the soil resistance, namely $\mathrm{BD}, \mathrm{MC}$ and soil depth (d) were not taken into consideration.

3 Based on a combination of a finite element and multiple linear regression analyses,

4 Mouazen et al. (2003a) developed the following model for the calculation of soil

5 compaction indicated as BD that was valid for a sandy loam field (Zoutleeuw 1 Field in

6 Table 1):

7

$8 \quad B D=\left(\sqrt[3]{\frac{D+21.36 M C-73.9313 d^{2}}{1.6734}}\right)$

9

10 where $D$ is subsoiler draught $[\mathrm{kN}], M C$ is gravimetric moisture content $\left[\mathrm{kg} \mathrm{kg}^{-1}\right], d$ is 11 cutting depth $[\mathrm{m}]$ and $B D$ is bulk density $\left[\mathrm{Mg} \mathrm{m}^{-3}\right]$.

12

Equation (1) was modified empirically for sandy loam field by adding an average correction factor (M) of 1.14 (Mouazen et al., 2003b), which was the average error of BD between calculated values using Eqn (1) and measurement values with the core sampling method:

$B D=\left(\sqrt[3]{\frac{D+21.36 M C-73.9313 d^{2}}{1.6734}}\right) \times 1.14$

9 Using Eqn (2), soil compaction indicated as BD can be determined on-line, if D of the cutting tool (subsoiler), cutting d and MC are measured on-line (Mouazen and Ramon 2006). So far, Eqn (2) was tested and validated for sandy loam field (Zoutleeuw 1 field in Table 1) (Mouazen et al., 2003b; Mouazen and Ramon 2006), for which BD may vary 
1 between 1.2 and $1.8 \mathrm{Mg} \mathrm{m}^{-3}$ (Bardy, 1984). For a new soil texture other than sandy loam

2 and loam, a field experiment is needed to establish a new $M$ valid for a texture dominated 3 in a field.

4 This study aims to modify a BD model established originally for a sandy loam field to be

5 used for loamy sand, silt loam, loam and silt soils by means of field experiments. The

6 reliability of the on-line BD map was investigated, for one example field, by comparing

$7 \quad$ with a BD map measured with the traditional core sampling method.

8

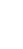

\section{Materials and methods}

\subsection{On-line measurement system of bulk density}

A standard medium-deep subsoiler used as soil cutting tool was attached to a frame, which was mounted onto the three point hitch of the tractor. The subsoiler consisted of two parts; the chisel of $0.06 \mathrm{~m}$ width, and the shank of $0.03 \mathrm{~m}$ width (Mouazen et al., 2003a). In addition to the sensor electrical system, a commercially available single ended shear beam load cell from CELTRON TECHNOLOGIES Inc. used to measure subsoiler D, a wheel gauge equipped with a linear variable differential transducer (LVDT) to measure $\mathrm{d}$ and a visible and near infrared spectrophotometer to measure MC were used. A more detailed description about the on-line measurement system can by found in Mouazen and Ramon (2006).

\subsection{Experimental fields and measurement}


The field experiments were carried out in four fields spread over an area of $50 \mathrm{~km}$ in diameter at east of Brussels. These experimental fields are located in Zoutleeuw, Heverlee, Leefdaal and Lovenjoel villages, in which measurements were carried out after wheat harvest in summer 2003 and after maize harvest in fall 2004, 2005 and 2006, respectively. The size of these fields varied between 7 ha (Zoutleeuw) and 1 ha (Lovenjoel). The soil texture fractions were determined by a combination of wet sieve and hydrometer tests, using the United State Department of Agriculture (USDA) soil classification. The average textures of the experimental fields down to a depth of $0.2 \mathrm{~m}$ were sandy loam, loam, silt loam and silt loam/silt textures, as given in Table 1 and Fig. (2a). Soil organic matter of the studied fields determined by the method of dry combustion is reported in Table 1. It should be noticed that in Table 1 and Fig. (2a), two Zoutleeuw fields were indicated. In fact, they are the same field, but Zoutleeuw 2 is larger in size and includes Zoutleeuw 1, for which results about on-line measurement of soil compaction was reported previously (Mouazen and Ramon, 2006). In all fields, average field texture was considered by collecting an average sample from arbitrarily selected spots in the field, except Lovenjoel field where average line texture was considered. In Lovenjoel field 6 experimental lines were selected, for which 6 different average line textures were obtained (Figs. $2 b$ and 3). In this particular field, soil becomes heavier throughout the South - North direction (Table 2 and Fig. 3), which can be attributed to the influence of slope. In this direction silt increases considerably, while only slight increase in clay takes place.

After setting up the different sensors, the subsoiler was pulled throughout parallel lines of $10 \mathrm{~m}$ apart, as shown in Fig. (3) for Lovenjoel field, as an example. The subsoiler was driven at a travel speed of $1200-1500 \mathrm{~m} \mathrm{~h}^{-1}$, setting the chisel tip at a $\mathrm{d}$ of $0.15 \mathrm{~m}$. Before 
7 $8 \quad 0.12-0.15 \mathrm{~m}$.

10

11

\section{Results}

measurement of each line, samples of soil were collected at each $10 \mathrm{~m}$ distance (Fig. 3) with Kopecki rings (a core sampling device), whose cylinder volume was $100 \mathrm{~cm}^{3}$ with 5 $\mathrm{cm}$ height. These samples were used for the determination of BD and MC by the oven drying method $\left(105^{\circ} \mathrm{C}\right.$ for 24 hours). They were collected just before running the subsoiler to eliminate error in measuring BD due to soil loosening by the subsoiler. Since the variation of $\mathrm{BD}$ of the topsoil was the point of interest of this study, core samples were taken at a shallow $\mathrm{d}$ by pushing the cylinder bottom within the soil down to a d of about

\subsection{Development of $B D$ maps}

The ARCVIEW GIS 3.1 software was used to develop the BD maps. All BD maps were developed based on a $10 \mathrm{~m}$ by $10 \mathrm{~m}$ data grid in order to harmonise the resolution of all maps (Fig. 3). The grid was interpolated using the inverse distance weighing (IDW) method. The interpolation grid size of all maps had a radius of $25 \mathrm{~m}$ and a power of 2 , with a map cell size of $1 \mathrm{~m}^{2}$.

\subsection{Maps of bulk density}

Although data of BD are available for all four fields, only Lovenjoel field will be selected, as an example, to discuss BD maps. This is done because the soil texture for each of the six measurement lines of Lovenjoel field was measured (Table 2), which will be 


\section{Soil and Tillage Research, Volume 103, Issue 1, April 2009, Pages 98-104}

1

2

3

5

6 field texture sample.

7 MC and textures. model

more beneficial to understand the correlation between $\mathrm{BD}$ and texture variation over the fields. In the other three fields, texture was determined based on one average sample selected randomly over a field area. Table 2 shows the presence of texture variation in Lovenjoel field even over the small field area of about 1 ha. This texture variation confirms that the actual spatial variation in field texture can not be represented by only one average

Spatial similarity between on-line measured (Eqn 1) and core sampling measured BD maps (Fig. 4) can be determined by visual comparison. Compaction zones are properly detected by the on-line compaction sensor. However, using the on-line sensor and the compaction model of Eqn (1) without incorporating M provided under-estimation of BD. This under-estimation was remarkably clear for all studied fields except for that of Heverlee field (Table 3), in which MC was the largest (average of $0.279 \mathrm{~kg} \mathrm{~kg}^{-1}$ ) as compared to the other fields. Furthermore, the degree of under-estimation of BD for the three fields (Zoutleeuw, Lovenjoel and Leefdaal) was different. This emphasises the need for further investigation to figure out the reason of the under- or over-estimation of BD obtained from the on-line sensor and the compaction model of Eqn (1) under different soil

\subsection{Evaluation of the effect of different measurement parameters on error of bulk density}

In order to evaluate the reason for variable estimation of BD using Eqn (1) and on-line sensor among different measurement fields, simple plots of MC vs $\mathrm{M}$ for all measurement 
1 points $(\mathrm{M}$ = measured $\mathrm{BD}$ with core sampling method / on-line measured BD using Eqn

2 (1)), D vs $M$ and d vs $M$ are shown in Fig. 5. A total of 736 samples collected from the four

3 experimental fields were considered. A clear separation of the four field samples into 4

4 groups can only be seen in MC vs M plot. Furthermore, the clear decreasing trend of M can

5 only be seen with MC (Fig. 5a), suggesting the significant effect of MC on the accuracy of

6 the on-line measured $\mathrm{BD}$ and hence $\mathrm{M}$ of $\mathrm{BD}$ model (Eqn 1). The average calculated $\mathrm{M}$ at

7 field scale varied between 0.994 in Heverlee field (silt loam/silt soil with an average MC of

$8 \quad 0.279 \mathrm{~kg} \mathrm{~kg}^{-1}$ ) and 1.171 in Zoutleeuw 2 (loam soil with an average MC of $0.105 \mathrm{~kg} \mathrm{~kg}^{-1}$ ).

9 At almost the same texture, $\mathrm{M}$ varied between 1.171 (Zoutleeuw 2) for an average MC of

$10 \quad 0.105 \mathrm{~kg} \mathrm{~kg}^{-1}$ and 1.122 (Lovenjoel) for an average MC of $0.186 \mathrm{~kg} \mathrm{~kg}^{-1}$, which is a further

11 proof of the domination of $\mathrm{MC}$ effect on $\mathrm{M}$.

12 In order to quantify the effect of each of the measured parameters on M of BD model,

13 linear regression correlation between the average field value of a measured property (MC,

14 D, d, sand, silt and clay) and average calculated $M$ was carried out. All fields were 15 considered in the linear correlation, except Heverlee field, since the average MC of this 16 field was larger than the maximum MC considered to establish the BD model given by Eqn 17 (1). In fact, this BD model is valid for a MC range of 0.03 to $0.22 \mathrm{~kg} \mathrm{~kg}^{-1}$ (Mouazen et al., 2003a), which makes including calculations of Heverlee field with an average MC of 0.279 $\mathrm{kg} \mathrm{kg}^{-1}$ is incorrect. The values of the determination coefficient $R^{2}$ between average field M and average field measured parameters are given in Table 4. It is clear that all these correlations are rather weak, except the correlation between $\mathrm{MC}$ and $\mathrm{M}\left(\mathrm{R}^{2}=0.99\right)$, which is a proof of the large effect of MC on the accuracy of BD prediction using the model of Eqn (1). The correlation results between $M$ and silt and sand fractions are weak (Table 4), 
1 providing that no clear effect of the two main texture fractions (sand or silt) on $\mathrm{M}$ can be

2 established for the studied soils. Although among the three texture fractions the range of

3 variation was the smallest for clay $\left(83-175 \mathrm{gkg}^{-1}\right)$, the correlation between $\mathrm{M}$ and clay is

4 the largest and can be considered as moderate.

6

7

(6)

1

\subsection{Correction of BD model}

In order to establish a new $\mathrm{M}$ accounting for soil texture, a multiple linear analysis was carried out between MC (strong effect on M) and clay (moderate effect on M) and M. The result of the analysis of variance (ANOVA) of is shown in Table 5, which indicated a significant effect of only MC on M $\left(P<0.001, R^{2}=0.89\right)$. Since the MC had the ultimate effect on M, a simple linear regression (LR) analysis was also carried out between MC and M. The LR and MLR resulted in two new M, which are incorporated into Eqn (1) to obtain new BD models, written, respectively, as follow:

$$
B D=\left(\sqrt[3]{\frac{D+21.36 M C-73.9313 d^{2}}{1.6734}}\right) \times(1.240-0.592 M C-0.000792 \text { clay })
$$

$$
B D=\left(\sqrt[3]{\frac{D+21.36 M C-73.9313 d^{2}}{1.6734}}\right) \times(1.255-0.772 M C)
$$

Where clay is expressed in $\%$.

\section{Discussion:}




\section{Soil and Tillage Research, Volume 103, Issue 1, April 2009, Pages 98-104}

1

2

3

4

5

6

7

8

9

Equations (5 and 6) were used to calculate the corrected BD of Lovenjoel field by utilising the on-line measured $\mathrm{D}, \mathrm{MC}$ and $\mathrm{d}$. Due to the dominant effect of MC, both models provided similar prediction accuracies of BD and distribution of compacted zones. A slight improvement of Eqn (5) over Eqn (6) for capturing the high BD values was recorded. Therefore, the former equation was adopted to calculate the corrected BD and to develop a corrected BD map. This corrected on-line BD map (Fig. 6) is quite similar to the corresponding map measured with the core sampling method (Fig. 4a). The spatial distribution of the corrected BD map of Fig. (6) is better than the calculated uncorrected BD map (Fig. 4b) as visually compared to that of measured BD with the core sampling method (Fig. 4a). The improvement reflected not only on the spatial distribution of BD, but also on the linear correlation between on-line and core sampling methods. This correction resulted in a higher $R^{2}$ value of 0.52 between the corrected on-line measured $\mathrm{BD}$ and the core sampling measured $\mathrm{BD}$, as compared to that of the uncorrected on-line measured $\mathrm{BD}$ and sampling measured $\mathrm{BD}\left(R^{2}=0.47\right)$.

The BD error between the core sampling method and the on-line method in Lovenjoel field is shown in Fig. 7. A large skewness resulted from the under-estimation of BD model without correction (Eqn 1) is shown in Fig. 7a. By using the corrected model of Eqn 5, the error becomes normally distributed around zero (Fig. 7b). The error of the corrected on-line measured $\mathrm{BD}$ ranges from -0.231 to $0.217 \mathrm{Mg} \mathrm{m}^{-3}$ with a standard deviation and average error of $0.087 \mathrm{Mg} \mathrm{m}^{-3}$ and $0.001 \mathrm{Mg} \mathrm{m}^{-3}$ (Table 6), respectively. Table 6 also proves that the average relative error was considerably smaller in correspondence to the corrected BD $(0.07 \%)$, as compared to the uncorrected BD (10.97\%). Indeed, the improved results of 
1 on-line measured BD after correction with Eqn (3) recorded not only for Lovenjoel field 2 but on the other two experimental fields (Table 6).

In spite of the fact that Lovenjoel field is of variable textures of loamy sand, sandy

4 loam, loam, and silt loam textures (Table 2 and Fig. 2b), the combination of the on-line 5 measurement system and corrected BD model (Eqn 5) is capable to detect the spatial 6 variation of soil compaction indicated as BD. Furthermore, although soil becomes heavier 7 throughout the South - North direction (Table 2 and Fig. 3), along with BD is expected to 8 decrease, the on-line sensing system was capable to capture the compacted spots at the 9 northern edge (heaviest part) of the field. This implies that the studied texture classes those 10 located at the base of the texture triangle of the USDA classification system need no further 11 calibration of BD model as long as the clay content does not exceed $200 \mathrm{~g} \mathrm{~kg}^{-1}$ (83 to $175 \mathrm{~g}$ $12 \mathrm{~kg}^{-1}$ ). For these texture classes M is mainly affected by MC and minimally by clay content, which might be due to the small range of clay variation. The promising readings of the error statistics between the core sampling and corrected on-line measurements of BD is the proof for the successful expansion of the BD model for new experimental fields with different textures of loamy sand, sandy loam, loam, silt loam and silt. It is recommended to carry out similar calibration procedure of the on-line measurement system for another soil textures with bigger variation in clay content in order to establish general correction factors, allowing the on-line measurement system to be of possible use for all available textures in agricultural soils. The texture triangle of the United State Department of Agriculture (USDA) has to be divided into 3-4 parts, for each a calibration factor has to be developed.

\section{Conclusions}


1

2

3

4

5

6

7

8

9

10

The possibility of expanding the use of an on-line measurement system of soil compaction indicated as bulk density (BD) from sandy loam field to loamy sand, loam, silt loam and silt soils was investigated. Experiments were performed in four experimental fields to compare between the Kopecki rings (core sampling method) and on-line measured $\mathrm{BD}$, aiming at establishing a new correction factor (M) of $\mathrm{BD}$ model proper for the soils investigated. From the results obtained, the following conclusions can be drawn:

- The gravimetric soil moisture content (MC) has the only significant effect $(P<$ $0.001, R^{2}=0.86$ ) on $\mathrm{M}$ and subsequently on the on-line predicted $\mathrm{BD}$.

- The soil clay fraction has the largest effect on $\mathrm{M}$ as compared to silt and sand fractions, although this effect was found to be small $(\mathrm{P}=0.527)$. However, a slight improvement for capturing the high BD values was obtained when the clay content was included in the multiple linear regression (MLR) analysis together with MC.

- A new M that accounts for variable MC and clay was recommended to be incorporated into BD model, which led to smaller errors and better spatial distribution of BD obtained by the on-line measurement system.

- The previously developed BD model used for on-line measurement system of soil compaction can be expanded for new soil textures, namely, loamy sand, loam, sandy loam, silt loam and silt textures.

- This calibration procedure is only valid for limited variation in clay content (e.g. 83 $\left.-175 \mathrm{gkg}^{-1}\right)$. 
1 To account for new soil textures than those considered in the current study, further field

2 experiments are needed to provide new $\mathrm{M}$, which might or might not be significantly

3 sensitive to texture variation.

4

5

6

7

Bardy, N. C., 1984. The Nature and Properties of Soils. $9^{\text {th }}$ Ed. MacMillan Publishing Co, New York, USA.

Glancey, J. L., Upadhyaya, S. K., Chancellor, W. J., Rumsey, J. W., 1989. An instrumented chisel for the study of soil-tillage dynamics. Soil \& Tillage Research, 14, 1-24.

Grossman, R. B., 1981. Bulk Density: Application, Estimation, and Field Management (second approximation). Nat. Soil Survey Lab., Soil Cons. Survey, Lincoln, NE.

Grossman, R. B., Berdanier, C. R., 1982. Erosion Tolerance for Cropland: Application of the Soil Survey Data Base. In Determinants of Soil Loss Tolerance, Chapter 10, ASA Sp. Publ. No. 45, p. 113-130 (ASA, CSSA and SSSA, Madison, WI, USA)

Hayhoe, H. N., Lapen, D. R., McLaughlin, N. B., Curnoe, W. E., 2002. Measurements of mouldboard plow draft: I. spectrum analysis and filtering. Precision Agriculture Journal, 3(3), 225-236.

Hemmat, A., Adamchuk, V. I., 2008. Sensor systems for measuring soil compaction: Review and analysis. Computers and Electronics in Agriculture, 63(2), 98-103.

Mouazen, A. M., Ramon, H., De Baerdemaeker, J., 2003a. Modelling compaction from online measurement of soil properties and sensor draught. Precision Agriculture Journal, 4(2), 203-212. 


\section{Soil and Tillage Research, Volume 103, Issue 1, April 2009, Pages 98-104}

1 Mouazen, A. M., Dumont, K., Maertens, K., Ramon, H., 2003b. Two-dimensional

2 prediction of spatial variation in topsoil compaction of a sandy loam field based on measured horizontal force of compaction sensor, cutting depth and moisture content. Soil \& Tillage Research, 74(1), 91-102.

Mouazen, A. M., Ramon, H., 2006. Development of on-line measurement system of dry bulk density based on on-line measured draught, depth and soil moisture content. Soil \& Tillage Research, 86(2), 218-229.

Neményi, M., Mesterházi, P. A. Milics, G. 2006. An application of tillage force mapping as a cropping management tool. Biosystems Engineering, 94(3), 351-357.

Singh, K. K., Colvin, T. S., Erbach, D. C., Mughal, A. Q., 1992. Tilth index: an approach to quantifying soil tilth. Transactions of ASAE, 35(6), 1777-1785.

Sprinkle, L. W., Langston, T. D., Weber, J. A., Sharon, N. M., 1970. A similitude study with static and dynamic parameters in an artificial soil. Transactions of ASAE, 29, 580586.

Verschoore, R., Pieters, J. G., Seps, T., Spriet, Y., Vangeyte, J., 2003. Development of a sensor for continuous soil resistance measurement. In: Precision Agriculture: Proceedings of the 4th European Conference on Precision Agriculture (Stafford J V and Werner A eds), pp. 689-695, Wageningen Academic Publishers, The Netherlands.

Upadhyaya, S. K., Williams, T. H., Kemble, L. J., Collins, N. E., 1984. Energy requirement for chiselling in coastal plain soils. Transactions of ASAE, 27(6), 1643-1649.

Vrindts, E., Mouazen, A. M., Reyniers, M., Maertens, K., Maleki, M., Ramon, H., De Baerdemaeker, J., 2005. Management zones based on correlation between soil compaction, yield and crop data. Biosystems Engineering, 92(4), 419-428. 

4 5 6 7 8 9 10 11 12 13 14 15 16

\section{Tables}

Table 1

Average soil texture defined according to the United State Department of Agriculture (USDA) Soil Classification and soil organic matter of the experimental fields

\begin{tabular}{llllll}
\hline & \multicolumn{5}{c}{ Fields } \\
\cline { 2 - 6 } & Zoutleeuw 1 & Zoutleeuw 2 & Leefdaal & Lovenjoel & Heverlee \\
Property & Sandy loam & Loam & Silt loam & Sandy loam & Silt loam/Silt \\
\hline Texture class & 563 & 514 & 135 & 548 & 90 \\
$\begin{array}{l}\text { Sand }(>50 \mu \mathrm{m}) \\
\left(\mathrm{g} \mathrm{kg}^{-1}\right)\end{array}$ & 362 & 403 & 690 & 358 & 778 \\
$\begin{array}{l}\text { Silt }(2-50 \mu \mathrm{m}) \\
\left(\mathrm{g} \mathrm{kg}{ }^{-1}\right)\end{array}$ & 75 & 83 & 175 & 94 & 132 \\
$\begin{array}{l}\text { Clay }(<2 \mu \mathrm{m}) \\
\left(\mathrm{g} \mathrm{kg}{ }^{-1}\right)\end{array}$ & 1.95 & 1.95 & 1.64 & 3.62 & 2.02 \\
$\begin{array}{l}\text { Soil organic matter } \\
(\%)\end{array}$ & & & & & \\
\hline
\end{tabular}

17

18

19

20

21

22

23

24

25 
14

\begin{tabular}{|c|c|c|c|c|c|c|}
\hline \multirow[b]{2}{*}{ Property } & \multicolumn{6}{|c|}{ Lines } \\
\hline & A & B & $\mathrm{C}$ & $\mathrm{D}$ & $\mathrm{E}$ & $\mathrm{F}$ \\
\hline Texture class & Sandy loam & Loamy sand & Sandy loam & Loam & Silt loam & Silt loam \\
\hline $\begin{array}{l}\text { Sand }(>50 \mu \mathrm{m}) \\
\left(\mathrm{g} \mathrm{kg}^{-1}\right)\end{array}$ & 674 & 831 & 752 & 474 & 346 & 207 \\
\hline $\begin{array}{l}\text { Silt }(2-50 \mu \mathrm{m}) \\
\left(\mathrm{g} \mathrm{kg}^{-1}\right)\end{array}$ & 239 & 108 & 169 & 429 & 545 & 660 \\
\hline $\begin{array}{l}\text { Clay }(<2 \mu \mathrm{m}) \\
\left(\mathrm{g} \mathrm{kg}^{-1}\right)\end{array}$ & 87 & 61 & 79 & 97 & 109 & 133 \\
\hline
\end{tabular}

Table 2

Average soil texture of the experimental lines of Lovenjoel field defined according to the United State Department of Agriculture (USDA) Soil Classification 
Table 3

Statistical data on bulk density (BD) measured with core sampling (CS), uncorrected (Eqn 1) on-line (UOL) and corrected (Eqn 5) online (COL) methods

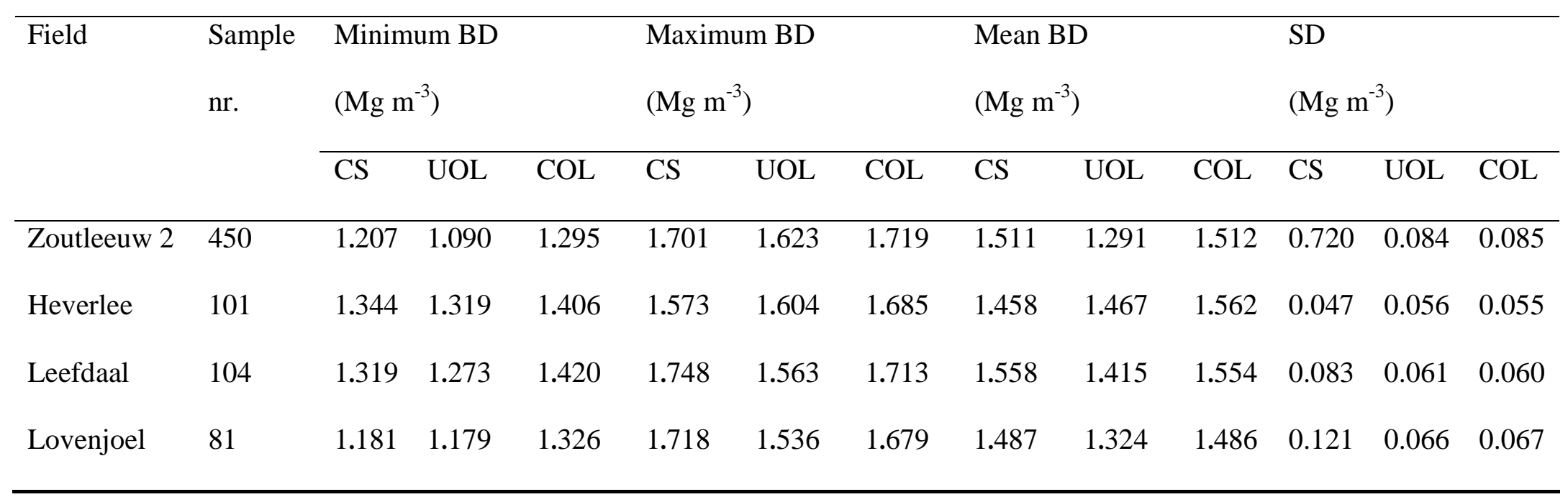

9

10

11 
Table 4

Determination coefficient $R^{2}$ values of the linear regression between the field average correction factor $(\mathrm{M})$ of calculated bulk density $(\mathrm{BD})(\mathrm{M}=$ (measured $\mathrm{BD} /$ predicted $\mathrm{BD}$ using Eqn (1)) vs field average measured parameters

\begin{tabular}{lllllll}
\hline $\begin{array}{l}\text { Moisture } \\
\text { content } \\
\left(\mathrm{kg} \mathrm{kg}^{-1}\right)\end{array}$ & $\begin{array}{l}\text { Sand } \\
\left(\mathrm{g} \mathrm{kg}^{-1}\right)\end{array}$ & $\begin{array}{l}\text { Clay } \\
\left(\mathrm{g} \mathrm{kg}^{-1}\right)\end{array}$ & $\begin{array}{l}\text { Silt } \\
\left(\mathrm{g} \mathrm{kg}^{-1}\right)\end{array}$ & $\begin{array}{l}\text { Draught } \\
(\mathrm{kN})\end{array}$ & $\begin{array}{l}\text { Depth } \\
(\mathrm{m})\end{array}$ & $\begin{array}{l}\text { Measured } \\
\text { bulk density } \\
\left(\mathrm{Mg} \mathrm{m}^{-3}\right)\end{array}$ \\
\hline 0.99 & 0.44 & 0.63 & 0.39 & 0.52 & 0.54 & 0.20 \\
\hline
\end{tabular}


Soil and Tillage Research, Volume 103, Issue 1, April 2009, Pages 98-104

$\mathbf{2}$

3

4

5

6 Analysis of variance (ANOVA) summary for clay and moisture content (MC)

\begin{tabular}{lllcc}
\hline Properties & units & B-coefficients & F-ratio & p-value \\
\hline MC & $\mathrm{kg} \mathrm{kg}^{-1}$ & -0.592 & 87.01 & $>0.0001$ \\
Clay & $\mathrm{g} \mathrm{kg}^{-1}$ & -0.000797 & 0.414 & 0.5273 \\
\hline
\end{tabular}

Table 5
9

10

11

12

13

14

15

16

17

18

19

20

21

22

23

24

25

26

27

28

29

30

31

32

33

34

35

36

37

38 
2

4

6

7

\begin{tabular}{llllll}
\hline Field & Field average & Field average error & Field average relative \\
& moisture content & $\left(\mathrm{Mg} \mathrm{m}^{-3}\right)$ & & error & \\
& $\left(\mathrm{kg} \mathrm{kg}^{-1}\right)$ & & & $(\%)$ & \\
\cline { 3 - 6 } & & & & & \\
& & & & & \\
\hline Zoutleeuw 2 & 0.105 & 0.220 & 0.000 & 14.58 & 0.06 \\
Leefdaal & 0.215 & 0.144 & 0.004 & 9.20 & 0.27 \\
Lovenjoel & 0.186 & 0.163 & 0.001 & 10.97 & 0.07 \\
\hline
\end{tabular}

Statistical data on error between measured bulk density (BD) with core sampling (CS) method and uncorrected (Eqn 1) on-line (UOL) and corrected (Eqn 5) on-line (COL) methods

(1)

9

10

11

12

13

14

15

16

17

18

19

20

21

22

23

24

25

26

27

28

29

30

31

Table 6 
2
Fig. 1. On-line measurement set up of bulk density (BD) ready for on-line field measurement (after Mouazen et al., 2005)

Fig. 2. Soil texture classification based on the United State Department of Agriculture (USDA) classification system of (a) the average texture of experimental fields of Zoutleeuw 1 (1), Zoutleeuw 2 (2), Leefdaal (3), Lovenjoel (4) and Heverlee (5) and (b) the average texture per measured line of Lovenjoel field

Fig. 3. Sampling and map design based on a $10 \mathrm{~m}$ by $10 \mathrm{~m}$ grid for Lovenjoel field test

Fig. 4. Comparison of bulk density (BD) maps for Lovenjoel field measured with the core sampling method (a) and on-line sensor using Eqn (1) (b), based on $10 \mathrm{~m}$ by $10 \mathrm{~m}$ grid Fig. 5. Illustration of the effect of measured parameters on correction factor $(\mathrm{M})(\mathrm{M}=$ measured bulk density (BD) with core sampling method / on-line measured BD using Eqn. 1) of BD model of the four experimental fields; (a) moisture content (MC) vs M, (b) draught (D) vs M, (c) depth (d) vs M

Fig. 6. Corrected on-line measured bulk density (BD) map for Lovenjoel field based on 10 $\mathrm{m}$ by $10 \mathrm{~m}$ grid 
Soil and Tillage Research, Volume 103, Issue 1, April 2009, Pages 98-104

Fig. 7. Histogram plot of bulk density (BD) error (measured BD with core sampling

2 method - on-line measured BD) for Lovenjoel field before correction using Eqn (1) (a) and

3 after correction using Eqn (5) (b) 
Soil and Tillage Research, Volume 103, Issue 1, April 2009, Pages 98-104

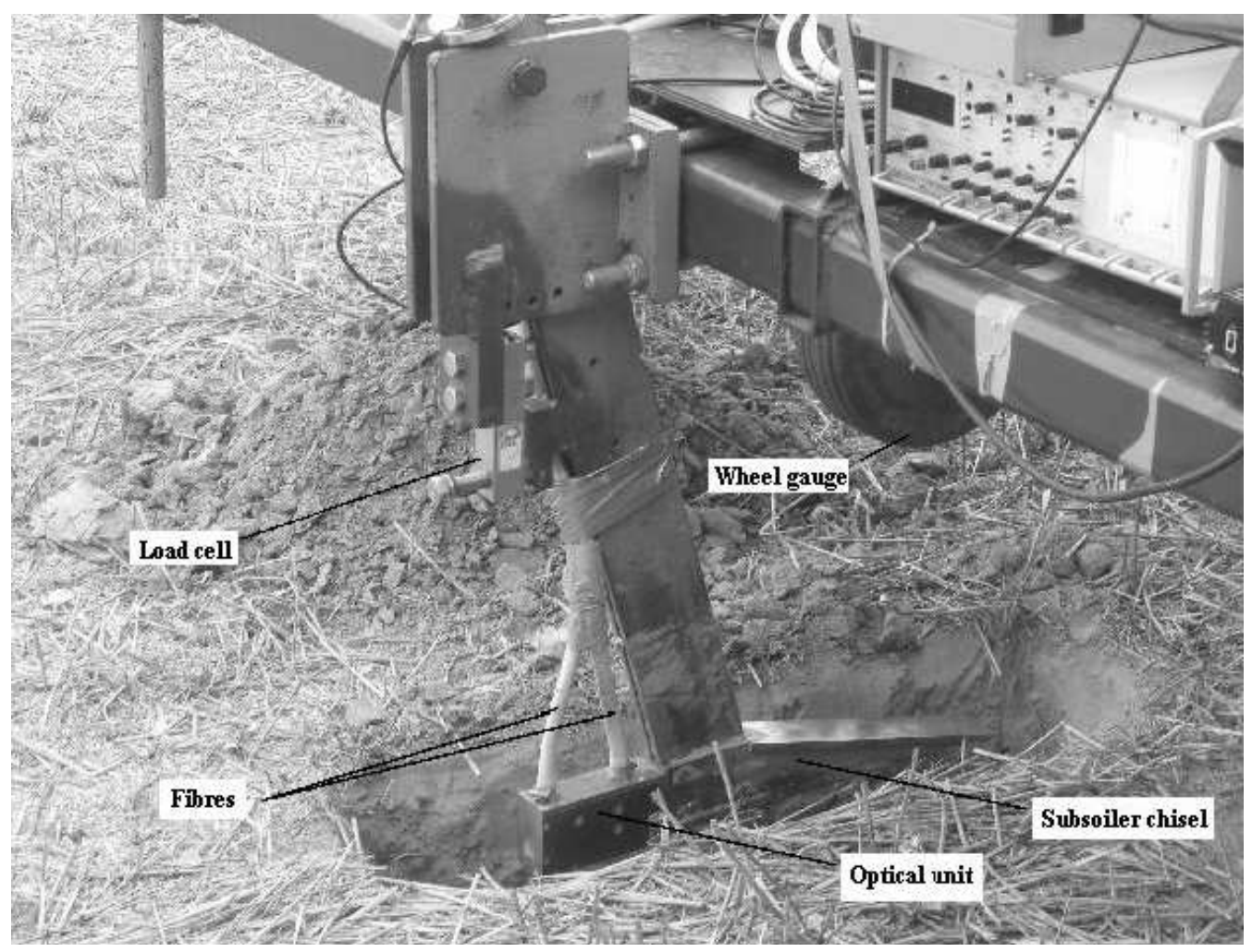

Fig. 1. On-line measurement set up of bulk density (BD) ready for on-line field measurement (after Mouazen et al., 2005) 
Soil and Tillage Research, Volume 103, Issue 1, April 2009, Pages 98-104

\section{USDA Texture Triangle}

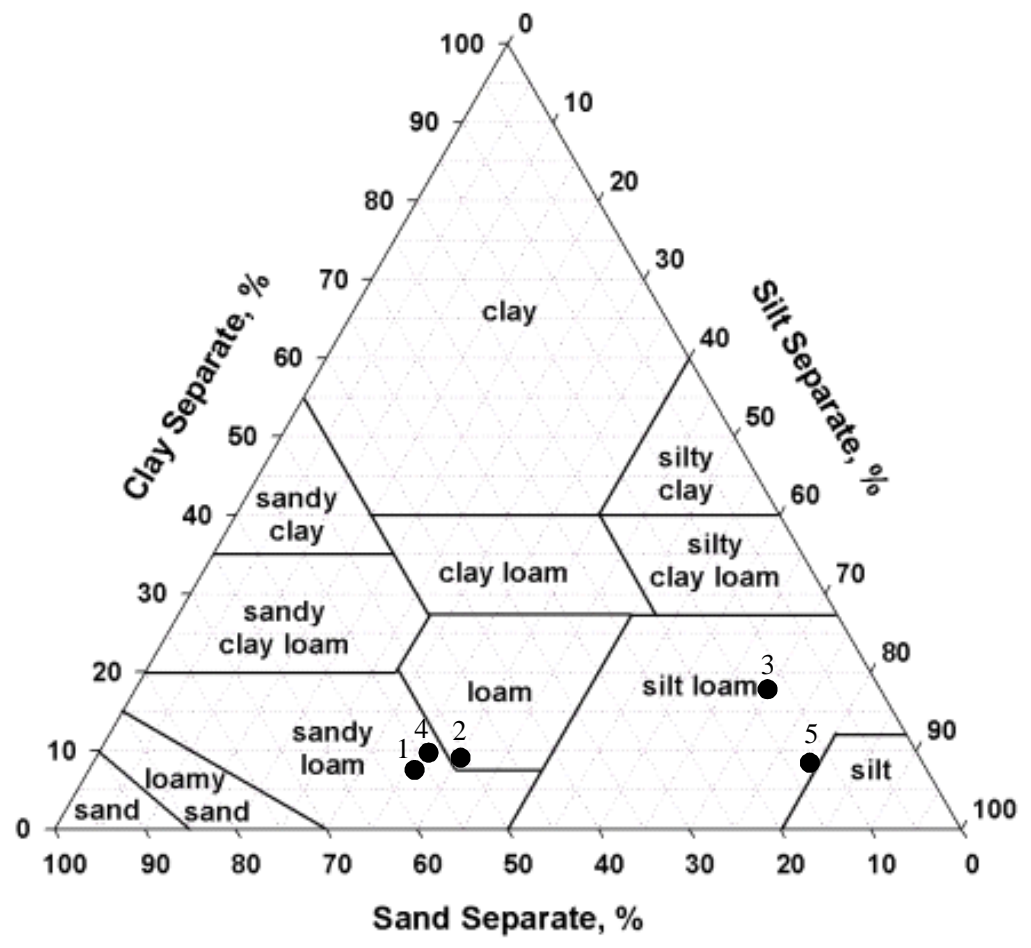

Fig. $2 a$ 
Soil and Tillage Research, Volume 103, Issue 1, April 2009, Pages 98-104

\section{USDA Texture Triangle}

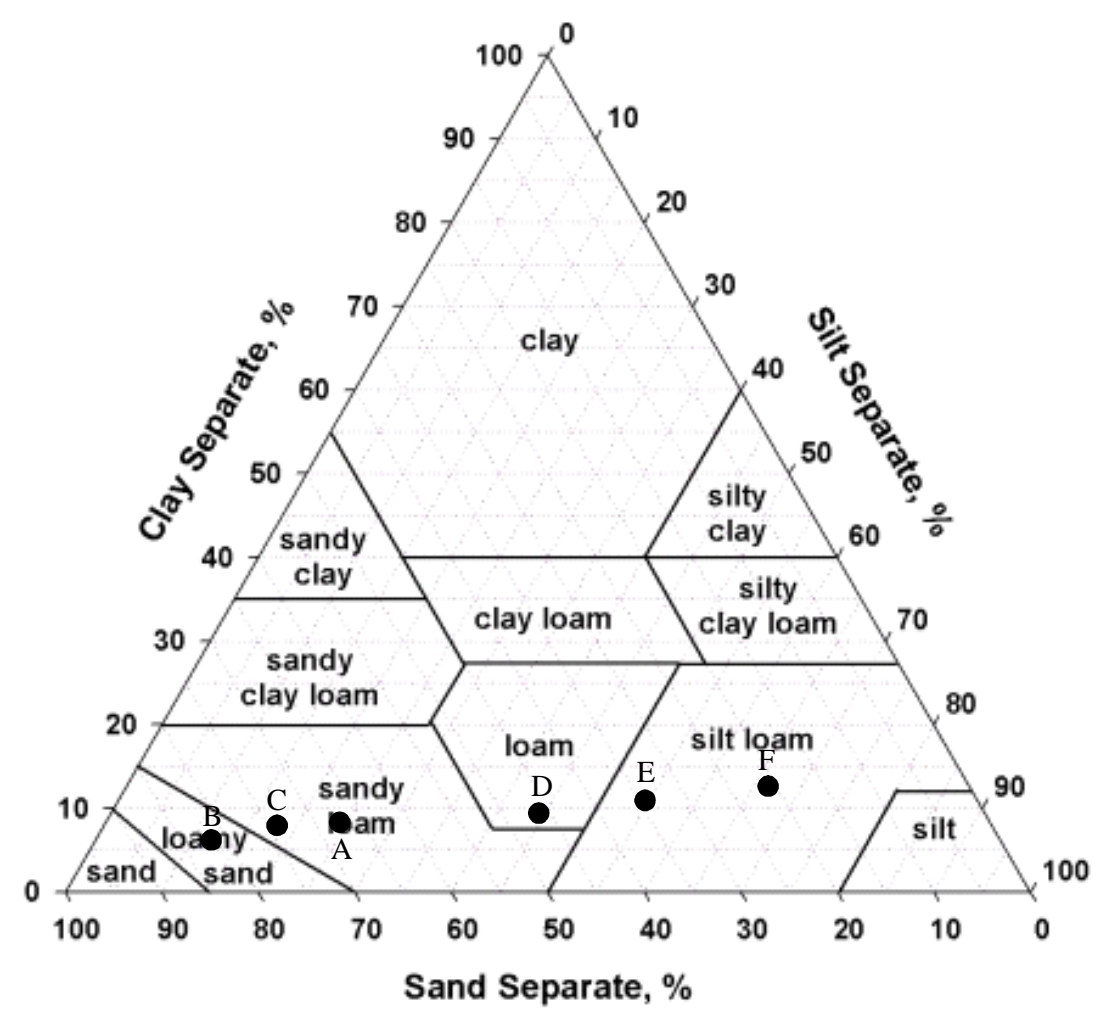

(Fig. 2b)

Fig. 2. Soil texture classification based on the United State Department of Agriculture (USDA) classification system of (a) the average texture of experimental fields of Zoutleeuw 1 (1), Zoutleeuw 2 (2), Leefdaal (3), Lovenjoel (4) and Heverlee (5) and (b) the average texture per measured line of Lovenjoel field 
Soil and Tillage Research, Volume 103, Issue 1, April 2009, Pages 98-104

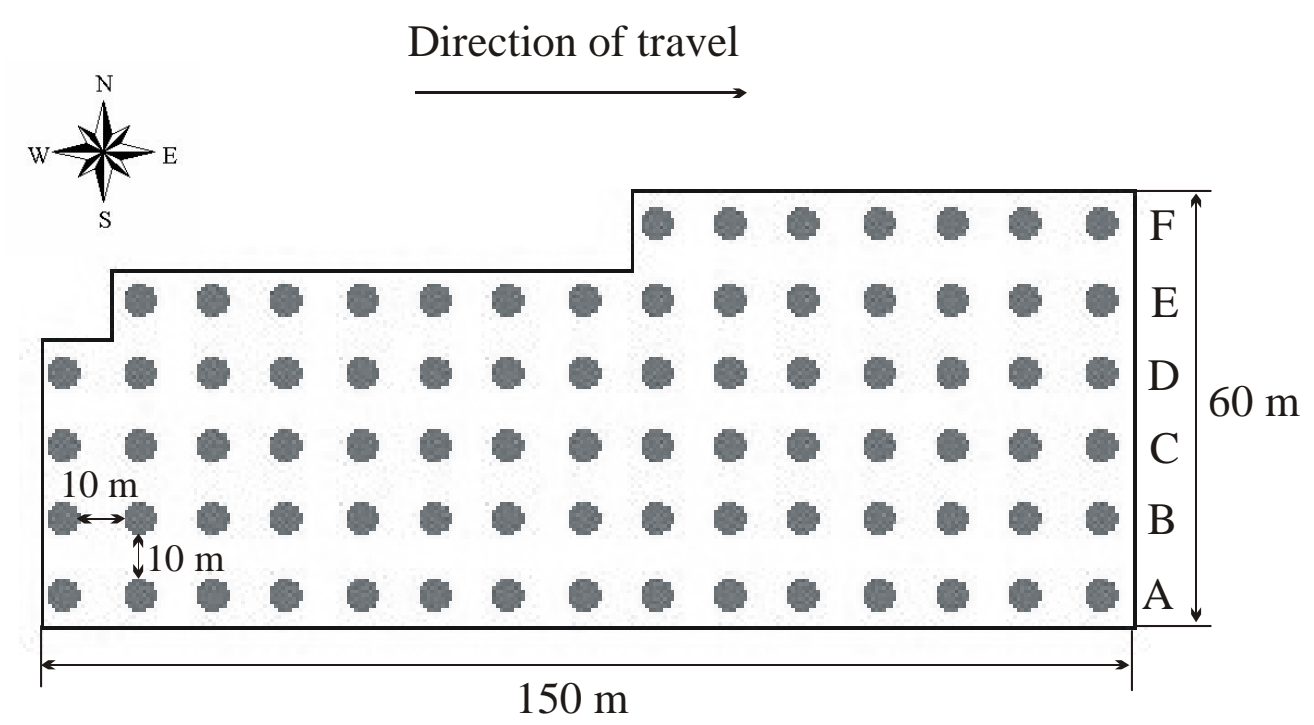

Fig. 3. Sampling and map design of Lovenjoel field based on a $10 \mathrm{~m}$ by $10 \mathrm{~m}$ grid for Lovenjoel field test 
Soil and Tillage Research, Volume 103, Issue 1, April 2009, Pages 98-104
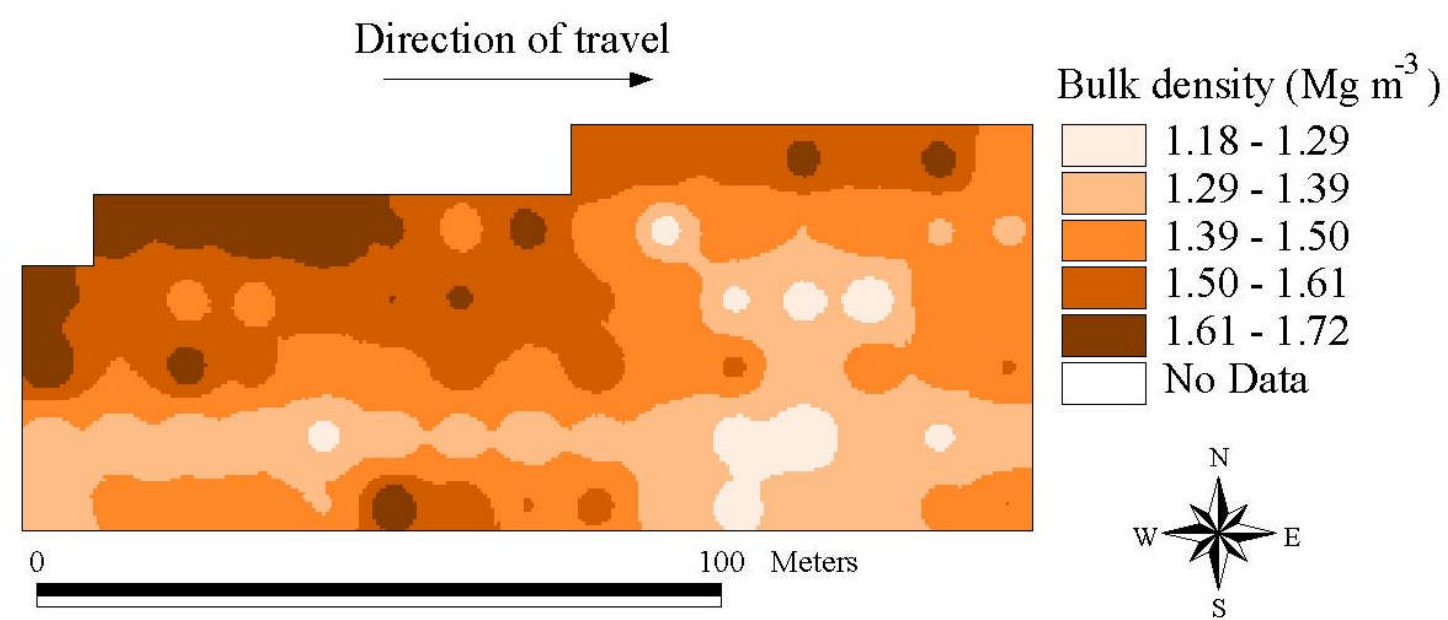

Fig.4a

Direction of travel

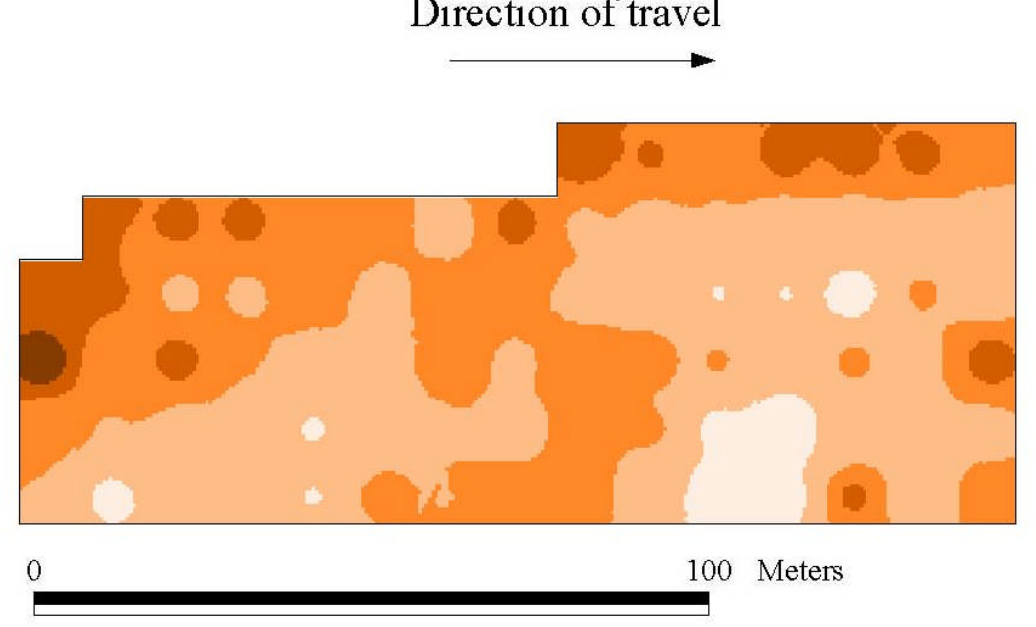

Bulk density $\left(\mathrm{Mg} \mathrm{m}^{-3}\right)$

Fig. $4 b$

Fig. 4. Comparison of bulk density (BD) maps for Lovenjoel field measured with the core sampling method (a) and on-line sensor using Eqn (1) (b), based on $10 \mathrm{~m}$ by $10 \mathrm{~m}$ grid 
Soil and Tillage Research, Volume 103, Issue 1, April 2009, Pages 98-104

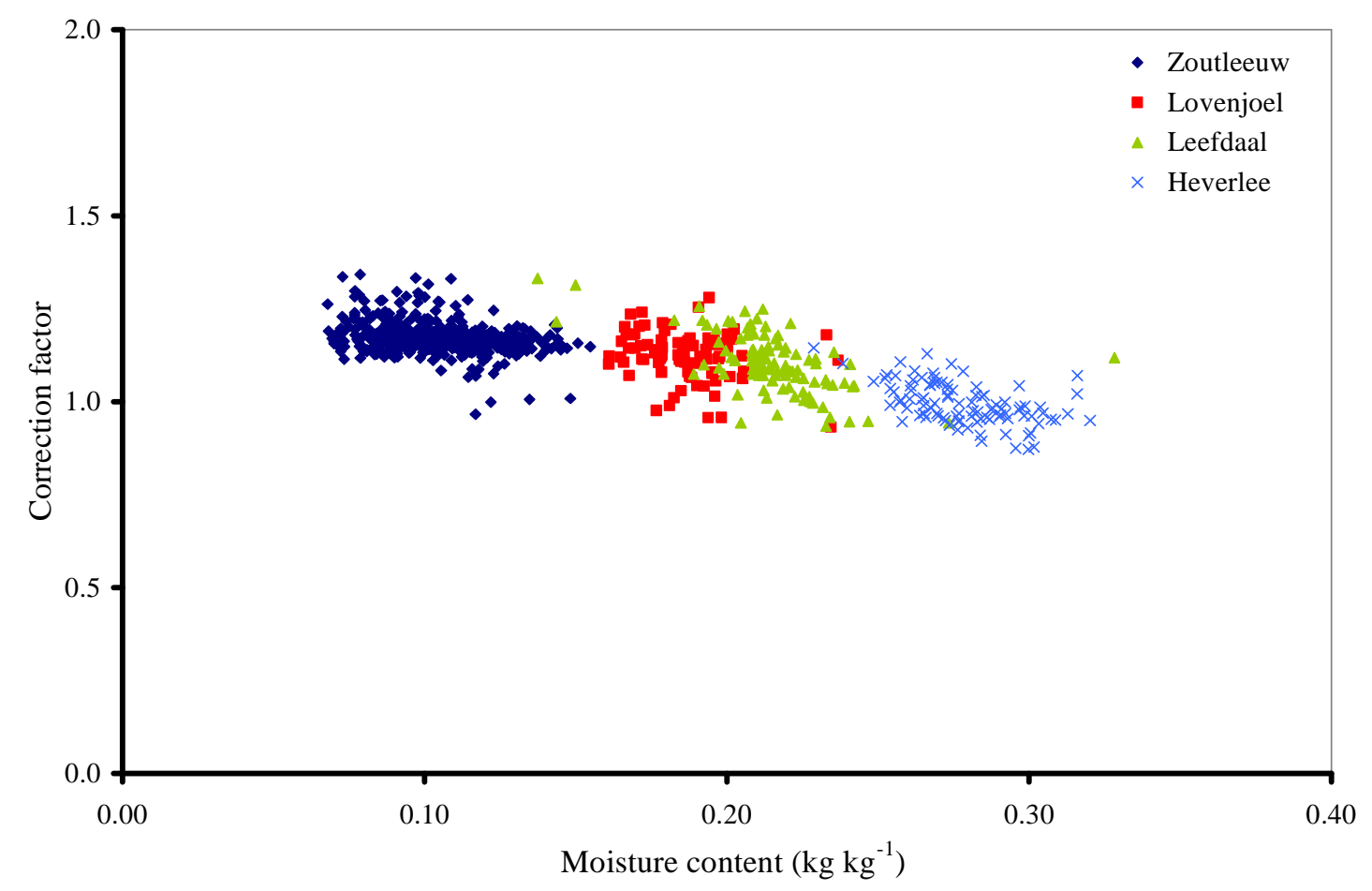

Fig. $5 a$ 
Soil and Tillage Research, Volume 103, Issue 1, April 2009, Pages 98-104

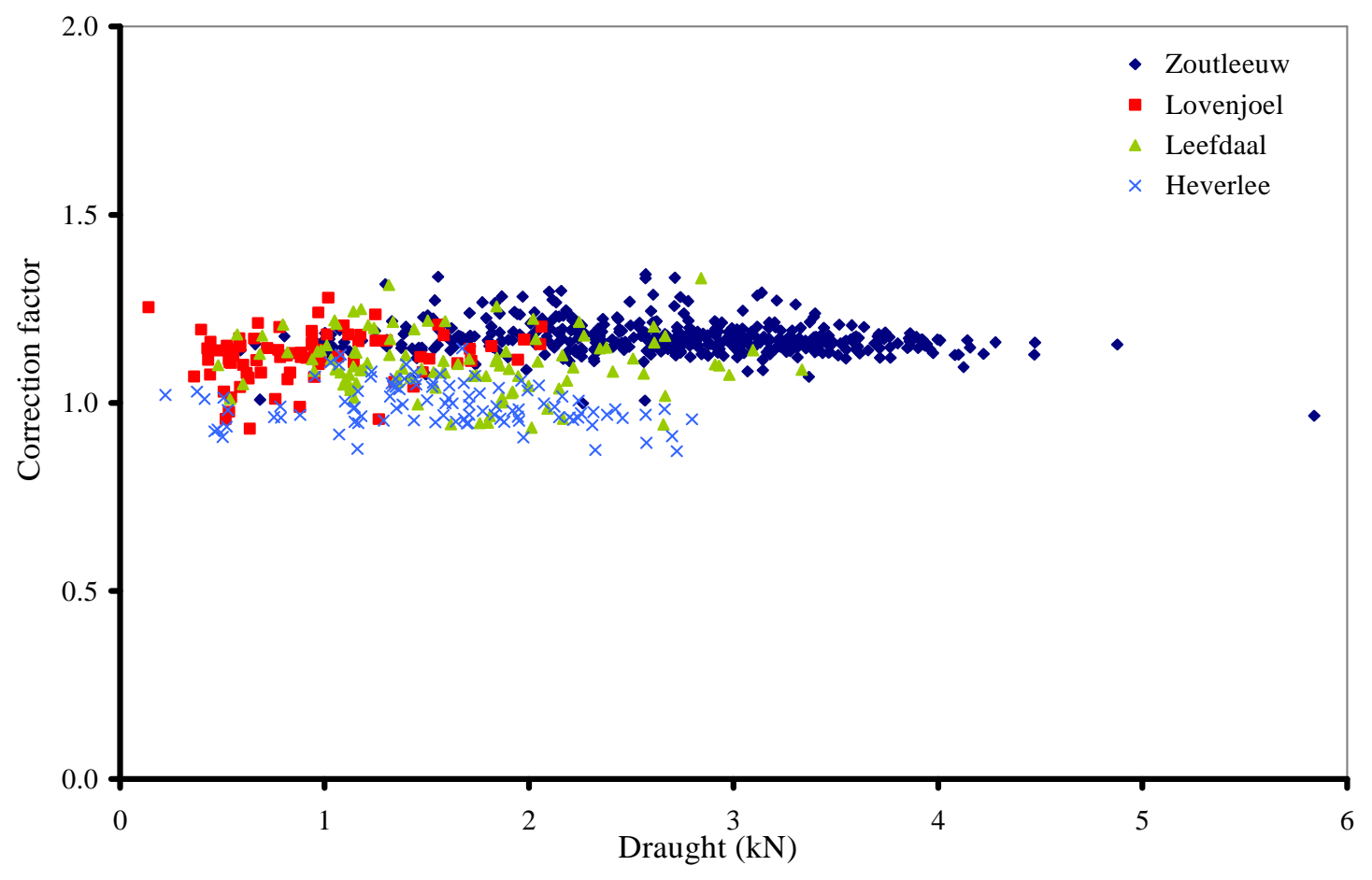

Fig. $5 b$ 
Soil and Tillage Research, Volume 103, Issue 1, April 2009, Pages 98-104

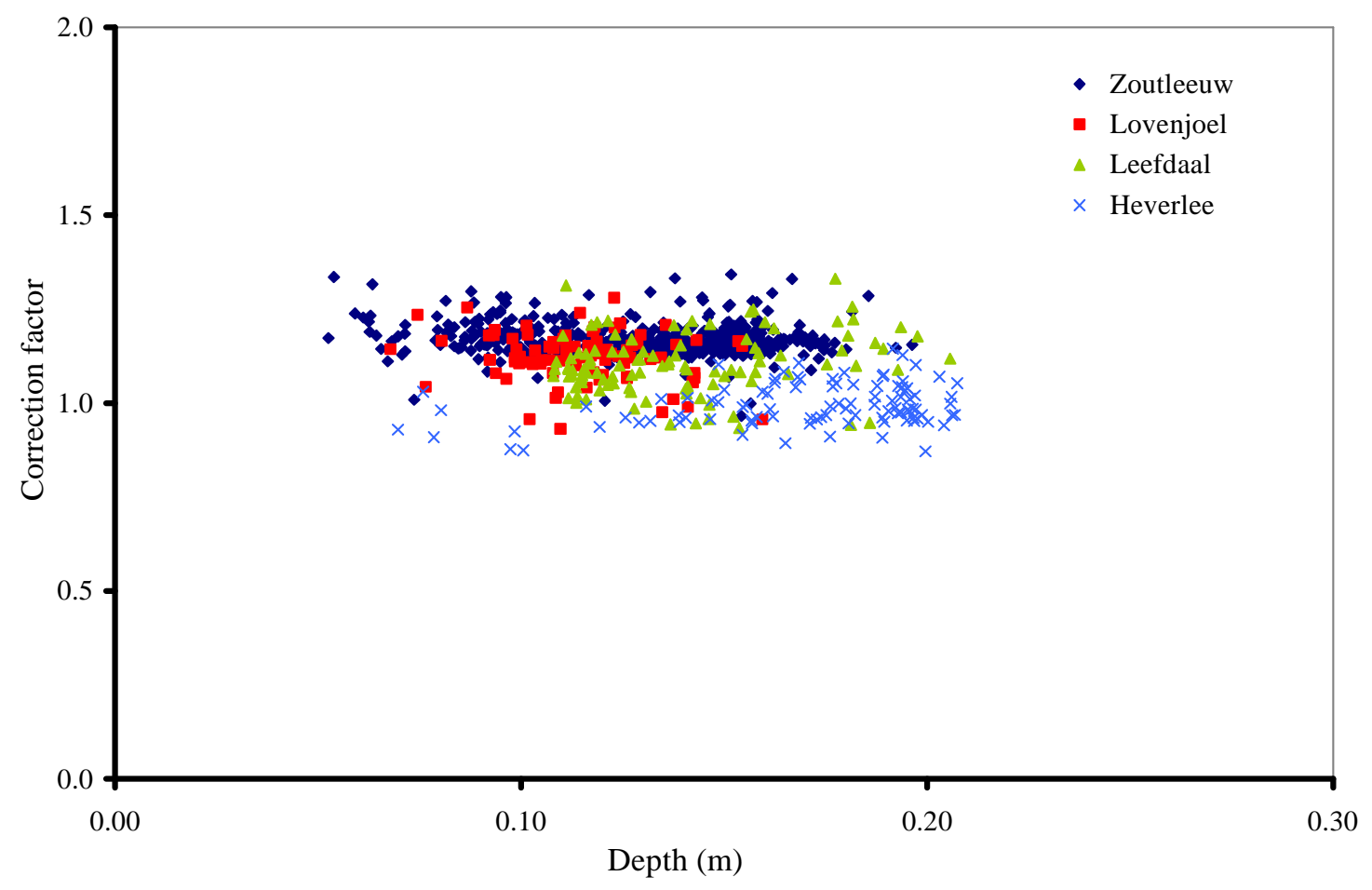

Fig. 5c

Fig. 5. Illustration of the effect of measured parameters on correction factor (M) $(\mathrm{M}=$ measured bulk density (BD) with core sampling method / on-line measured BD using Eqn. 1) of BD model of the four experimental fields; (a) moisture content (MC) vs M, (b) draught (D) vs M, (c) depth (d) vs M 
Soil and Tillage Research, Volume 103, Issue 1, April 2009, Pages 98-104

\section{Direction of travel}

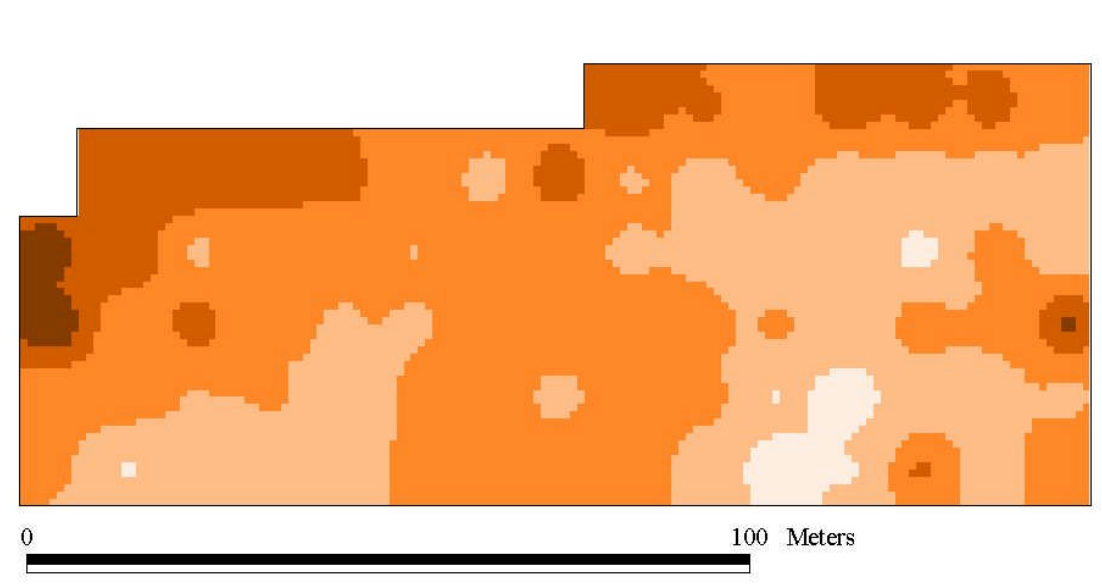

Bulk density $\left(\mathrm{Mg} \mathrm{m}^{-3}\right)$
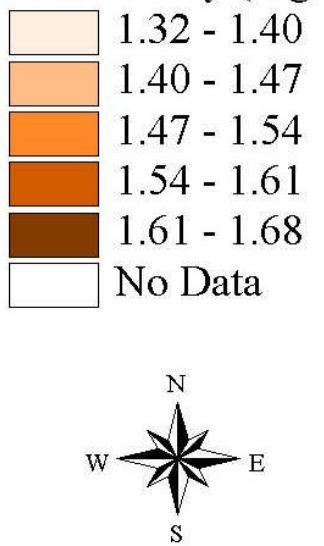

Fig. 6. Corrected on-line measured bulk density (BD) map for Lovenjoel field based on $10 \mathrm{~m}$ by $10 \mathrm{~m}$ grid 
Soil and Tillage Research, Volume 103, Issue 1, April 2009, Pages 98-104

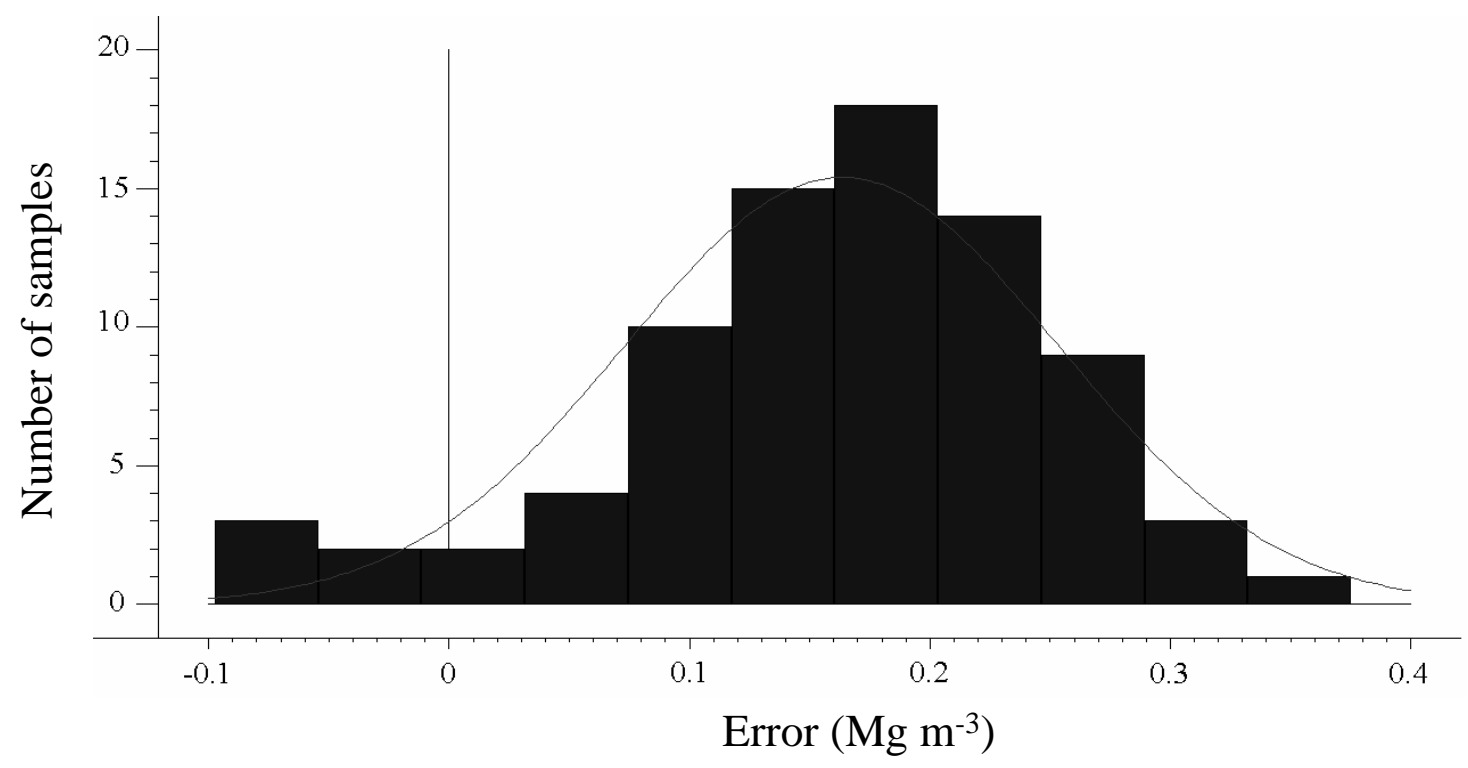

Fig. $7 a$

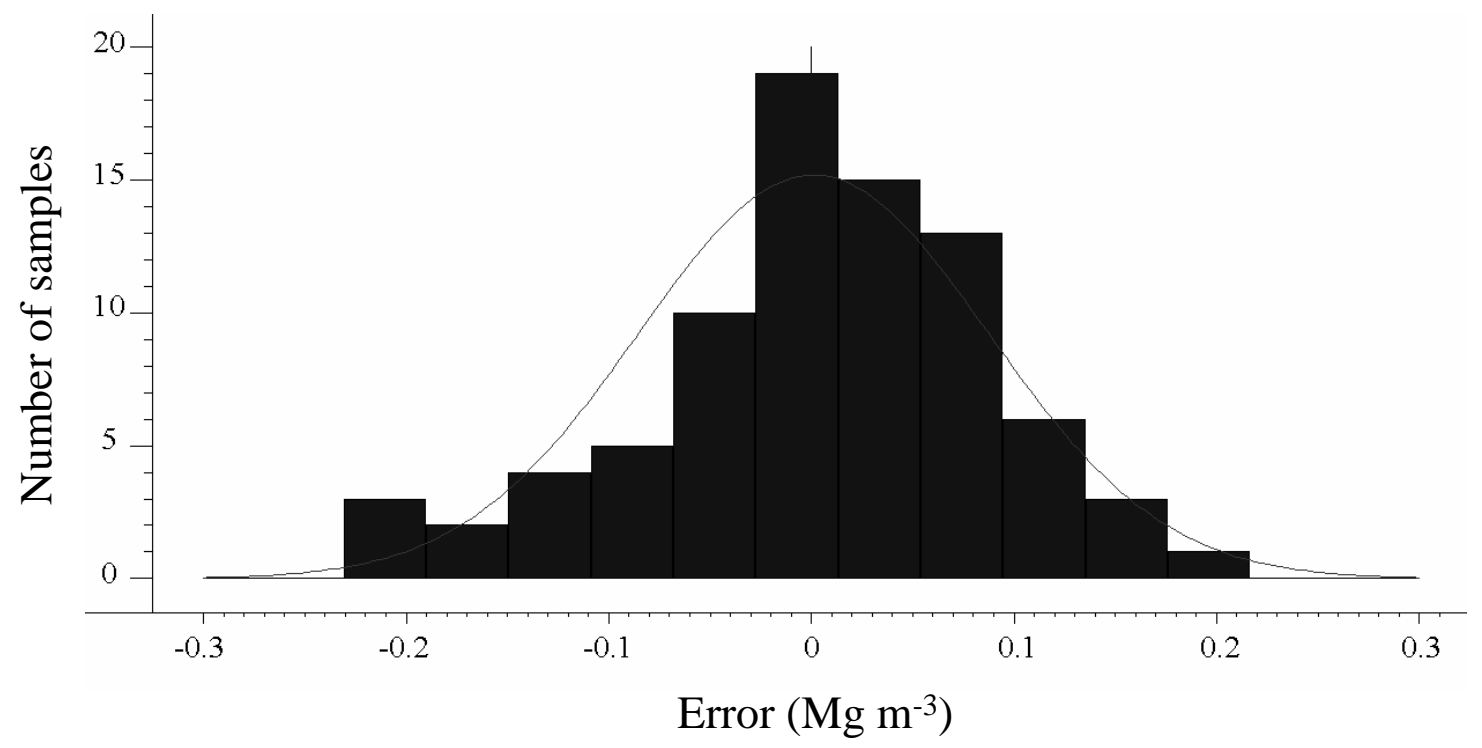

Fig. $7 b$

Fig. 7. Histogram plot of bulk density (BD) error (measured BD with core sampling method - on-line measured BD) for Lovenjoel field before correction using Eqn (1) (a) and after correction using Eqn (5) (b) 